\title{
Introduction: The Materiality of Traces and Legacies
}

\author{
Robert Paynter and Broughton Anderson, Department \\ of Anthropology, University of Massachusetts Amherst, \\ Massachusetts, USA \\ E-mail: rpaynter@anthro.umass.edu; banderson@anthro.umass.edu
}

Kimberly Kasper, Department of Anthropology, Rhodes College, Memphis, TN, USA

E-mail: kkasper@anthro.umass.edu

\section{ABSTRACT}

This Special Issue presents issues in contemporary archaeological theory and practice as influenced by the work of $\mathrm{H}$. Martin Wobst. Wobst came to study in the U.S. nearly 50 years ago and has contributed to many changes in the theory and practice of archaeology since then. Though the papers cover a wide range of topics they share common interests in seeing materiality as constitutive of culture, archaeologists as participants in the present as well as observers of the past, and an interest in transcending traditional definitions of archaeological research.

Résumé: Ce Numéro Spécial est consacré à l'influence de l'oeuvre de $\mathrm{H}$. Martin Wobst sur les problèmes de la théorie et de la pratique de l'archéologie contemporaine. Wobst vint étudier aux Etats-Unis il y a presque 50 ans et son travail a contribué depuis a de nombreux changements dans la théorie et la pratique de l'archéologie. Bien que les articles couvrent une grande variété de sujets, ils partagent une conception de la matérialité comme constitutive de la culture, des archéologues comme acteurs dans le présent et observateurs du passé, et un intérêt pour le dépassement des définitions traditionnelles de la recherche en archéologie.

Resumen: Esta Edición Especial presenta cuestiones sobre la teoría y práctica arqueológica contemporánea según la influencia de la obra de $\mathrm{H}$. Martin Wobst. Wobst vino a estudiar a los Estados Unidos hace casi 50 años y su obra ha contribuido a muchos cambios en la teoría y práctica de la arqueología desde entonces. Aunque los documentos cubren una amplia gama de temas, comparten intereses comunes en ver la materialidad como constitutiva de la cultura, a los arqueólogos como participantes en el 
presente así como también como observadores del pasado, y un interés en trascender las definiciones tradicionales de la investigación arqueológica.

\section{KEY WORDS}

Theory, Paleolithic, Materiality, Indigenous

\section{Introduction}

H. Martin Wobst has steadfastly sought to widen the field of vision of archaeology, in his publications, professional presentations, and in his classrooms. For his students, of whom the contributors within this Special Issue are a very small sample, he sought to foster an expansive and rigorous curiosity. As a result, these papers do not represent an orthodoxy. Instead, they exhibit a wide-ranging curiosity that seeks to redefine the traditional borders of the thought and practice of archaeology, a characteristic that is one of Wobst's most enduring contributions to the field.

Despite the range of topics addressed in this Special Issue, the papers do have interconnected themes. Though quite varied on the surface, these papers share deeper premises upon which their archaeology is based. An important tenet is that the material world is constitutive of culture as well as reflective of a way of life. In addition, the authors understand the past, as well as the present, as being made by human beings in particular material circumstances. They warily interrogate how archaeologists, including themselves, are situated in their study. They are productively skeptical about fundamental concepts, such as the valuing of the deep past over archaeologies of the near present, or in the name of "objectivity" valuing archaeologists' collaborations with academics over ones with various publics. And there is a sense in a number of the papers that archaeology should bring joy as well as enlightenment to our lives and those of people around us.

\section{Archaeology Today}

As reflected in the pages of Archaeologies, at meetings of the World Archaeological Congress (WAC), and in other professional venues, archaeologists find ourselves at an interesting juncture. An intense focus on culture histories has provided us with much broader and more richly nuanced understandings of the planet's many pasts. Accompanying this trend is the bewildering proliferation of theoretical positions, methodological approaches, and professional stances identified as "archaeology." The 
well-established approaches of culture history and processual archaeology are today joined by evolutionary archaeologies, Indigenous archaeologies, Marxist archaeologies, phenomenological archaeologies, feminist archaeologies, neo-ecological archaeologies, landscape archaeologies, historical archaeologies, nationalist archaeologies, colonial archaeologies, post-colonial archaeologies, heritage archaeologies, public archaeologies, CRM archaeologies, and so on. Some of these varieties of "archaeology" involve as much work on top of the ground as in it. And increasingly, we engage in research that crosses into the terrain of cultural and/or biological anthropologists.

These practices have affected how we think, talk, and write about our work. Archaeologists used to understand the field as a grand debate between neatly bundled theory-method-history schools of thought, individual billiard balls, if you will. Today our discussions are much more like a web where projects in one area can be more or less linked with projects in another, because they share some, but by no means all, interests and practices. The nodes in the web are ideas and projects around which people cluster, sometimes physically in the forms of academic departments or contract firms, and increasingly virtually, around websites, listserves, and blogs.

\section{Wobst in Archaeology}

The breadth of thinking in this Special Issue reflects many concerns found throughout the archaeological world. Their focus on some concerns rather than others results in no small measure from the authors' shared experiences in one of the nodes on the archaeological net, the Department of Anthropology at the University of Massachusetts Amherst, and especially the authors' relations with Martin Wobst.

Wobst joined the faculty at the University of Massachusetts Amherst in 1971, and has been an active member shaping the department's pedagogy and research direction for nearly its entire formal history (which began in 1969). The department has become known for research in areas outside the traditional geographical foci of anthropological inquiry, including Europe, the northeastern United States, and Madagascar. Its faculty and students have established reputations for pushing the social and intellectual boundaries of their respective subfields. Its student-centered, rather than canoncentered, graduate program has attracted students with a wide range of academic backgrounds and interests. Wobst's own research interests in the fundamental concepts of archaeology have allowed him to be a distinctive adviser, able to encourage students to be deeply and rigorously curious about whatever was the subject of their research. As a result, there is little overt intersection between his work and that of his students, but instead an easily identifiable similarity in their approaches to archaeology. 
Outside of the University of Massachusetts Amherst, Wobst is most widely known for contributions to archaeology's imaginings of the Paleolithic, his refinement of the concept of style, and his contributions to the growth of Indigenous archaeology. His 1971 Ph.D. dissertation modeling hunter-gatherer demography took the ideas of culture and sociability seriously in an era fascinated with ecology, and asked how many people must interact with one another to ensure the reproduction of any particular group, and hence of their way of life. Using computer simulations, Wobst discovered that this was a surprisingly large number, in the neighborhood of 500 . He was able to combine this quantitative result with his multilingual knowledge of the Paleolithic, to discern geographic and material implications, allowing him to breathe cultural contingency and the possibility of creativity into studies of this deep past (Wobst 1974a, b, 1976, 1979, 1983, 1990, 1993a).

"Style" was a fundamental feature of the 1960s New Archaeology's critique of the prevailing cultural history perspective, whose typologies were breaking down in the face of observed variation. Although a dominant line of critique made use of increasingly sophisticated multivariate methods, Wobst took a different tack and developed a theory of stylistic variation based on the nature of cultural information, knowledge, and perception. He exemplified his discursive approach to "style" by analyzing Yugoslavian ethnic clothing, especially hats. This began his career-long investigation into the constitutive nature of material culture, one that has led to the transformation of the more static concept of "style" into the more active notion of materiality, in which cultural agents are shaped by material culture as well as being the shapers of these material forms. As he pursued this line of inquiry, he developed signature phrases to capture this process, such as, material culture being "products of and precedents for action" and more recently in an activist framework by positing the material world as "interventions" in the practice of daily life (Wobst 1977, 1999, 2000a, 2006, 2011c, n.d.).

Wobst has followed these two streams-the Paleolithic past and materiality-with a method aimed at uncovering archaeologists' fundamental, almost unobserved, assumptions that in practice can lead to unintended and contradictory results. For instance, when he (1976) played his simulations of band society demographics out over the space of Western Europe it became immediately apparent that groups of artifacts attributed to separate "cultures" were more likely the handiwork of members of one or two large mating networks. In another study with Arthur Keene (1983), he presented the idea of "origin cones" to describe how archaeology's under-analyzed analytical procedures of typology resulted in ordering the archaeological data in ways that better reflect archaeological socio-politics rather than the past's historical processes. In addition, his analyses of the 
notion of "type" (Wobst 1992, 2000b, 2005b) show how its unconscious application populates the past with collections of cultural automatons, rather than immensely creative, and hence culturally diverse, groups of humans. Many of these ideas, along with wider ranging considerations about the place of archaeology in contemporary society, are found in his numerous reviews, epilogues, and meeting commentaries (Wobst 1989, 1991a, b, 1993b, 1998, 2009, 2011a, b). Often delivered with gentle humor, these commentaries to disclose the basic assumptions of the field and urge it in more humanistic and socially just directions. His work has found appreciative recognition in the literatures of people aligned with the New Archaeology (today's Processual Archaeology) as well as those aligned with its supposed opponent, the so-called Post Processual archaeologies.

A third major stream, Indigenous archaeology, had its beginnings with two conferences in Australia, the first in 1992 at a conference co-organized by Claire Smith entitled "Archaeology in the 1990s" at the University of New England, Australia, and even more so when he participated in a Fulbright Symposium in Darwin, Australia on "Indigenous Cultures in an Interconnected World," also co-organized by Claire Smith. From this emerged his professional work with Indigenous peoples and his dynamic collaboration with Smith. For nearly two decades, he has advised young Indigenous scholars, argued with obstinate keepers of the keys of the archaeological kingdom, and published thoughtful manifestos about how archaeology benefits when archaeologists work in solidarity with Indigenous peoples. WAC has been a major venue for his efforts, including his helping organize and serving on the editorial board of the WAC Indigenous Archaeologies Series He has further advanced Indigenous archaeology with his edited book with Smith (2005) and another with Bruchac and Hart (2010), articles and chapters (Bruchac et al. 2010; Smith and Wobst 2005; Wobst 2005a, 2009, 2010; Wobst and Smith 2000) and a wide circle of friends and fictive kin that extends far beyond the usual circuits of American archaeologists. Hard to pigeon-hole, Wobst has gone his own very distinctive way.

Because Wobst often worked with the deeper fundamentals of archaeological theory and practice, he was able to contribute to students working in a wide range of geographical and temporal settings. This wide range is clearly evident in the papers in this volume which are a very small, but assuredly representative sample of work by the 55 people who have received a Ph.D. and/or an M.A. under his direction. What they share with him is a sense of social responsibility, a questioning of traditional boundaries that mark the past from the present and "us" from "them," and a readiness to appreciate the creative potential of humanity, in its sadder and happier periods. It is to these papers that we now turn. 


\section{The Papers}

The papers presented in this Special Issue encompass a variety of thematic concepts and frameworks to bring forth diverse but nuanced perspectives on behavior and culture. Although each is developed under the author's unique line of inquiry, all seek to humanize the past and pay attention to the constitutive nature of presumably inert material culture. The papers cluster around three themes: (1) ethical implications of archaeological theory and method in the twenty-first century; (2) agency in Indigenous archaeology; and, (3) the materiality of us-present and past.

Three authors discuss the ethical implications of archaeological theory and method. Nicholas (this issue) draws inspiration from the work of Wobst and David Clarke, both of whose questionings of archaeology's fundamental concepts can make readers uneasy to this day. Using Clarke's thresholds for disciplinary development-namely the stages of consciousness, self-consciousness, and critical self-consciousness-Nicholas provides an overview of some of Clarke's untimely ended, and Wobst's ongoing efforts to provoke disciplinary movement over these thresholds. He discusses his own extensive work with Indigenous communities to demonstrate that archaeology's collaboration with twenty-first century descent communities is one of the more productive disciplinary developments in the move towards critical self-consciousness.

Chilton (this issue) discusses two examples of decolonizing archaeology. Both concern two Native American sites from the U.S. Northeast that she and student/colleagues investigated by using community collaborative approaches. For each case they sought to displace the archaeological perspective from the center of the planning and the conduct of the work. And the collaborations in both cases encountered stumbling blocks that will no doubt resonate with readers of Archaeologies. A self-critical assessment of both cases allows Chilton to offer a reinterpretation of the dichotomy of tangible and intangible heritage, and suggest that the decolonizing project be extended beyond archaeology to include all sorts of heritage practice and theory.

Weaving past, present, and future together, Labrador (this issue) questions the perspective that computerized archaeological databases and database management systems are neutrally objective, instead studying how they are products of and precedents for behavior and thought, and thereby important in the creation of archaeological meanings. She seeks to put archaeologists in control of these meaning-making machines, and thereby use them to open up access to the digital representations of the data and to multiple interpretations of their meanings. This openness, Labrador points out, will raise its own ethical dilemmas, requiring the development of new social relations and technological interventions. 
The second theme, concerning the study of and with Indigenous peoples in North America, begins with Sassaman (this issue) discussing the history of material interventions at the interface between nature and culture. Using the Floridian landscape over the last 7,100 years, he considers mound features as conspicuous materializations in the face of long-term climate change. Rather than exclusively seeking explanations in the physical characteristics of water level change and mound building activity, Sassaman suggests that they also had a basis in people's imaginings of novel futures. When archaeologists infuse the past with such historically specific social agents, he argues, the long history of Native Americans coping with the enigma of long-term climate change could become a source of inspiration as we ponder similar challenges today.

The papers by Kasper (this issue), and Hart and Bruchac (this issue) shift the focus to Native New England communities at the time of Contact, using artifacts, documents, and collaborative interactions to understand the materialities of two Native groups. Kasper uses archaeobotanical data and documentary research from Mashantucket Pequot reservation sites to examine long term, traditional ecological knowledge and its materialities across time and space. Shifting usage of particular seeds as the European invasion drastically altered the Pequots' access to traditional plants is evident in the archaeobotanical record. Whether in preserving the past or modifying their lifeways for the future, the Mashantucket Pequot drew from their experiences with medicinal plants in order to survive.

Hart and Bruchac (this issue) challenge the historically constructed story that the Pocumtuck of the middle Connecticut River Valley were a marginal group within a marginal region. Asking how they came to be considered marginal, Hart and Bruchac review past and present materializations of the Pocumtuck, the colonizers, and their relationships. They deploy a broad range of materials to uncover the complexity, influence, and power of the Pocumtuck people and thereby elevate the significance of the story of interior New England's colonial experience to that of the better-known stories of the collisions between the European colonizers and the peoples of the New England coast.

The third theme, whose studies assess the materiality of the present and the recent past to uncover the dynamics of power, space, and place, is "belted out of the park" by Green (this issue) in his study of the places where the sport of baseball is played. He asks what gives a cultural landscape, a place, its evocative power. He answers this by bringing an archaeological framework reflecting his previous work on Neolithic Europe to bear on the study of this iconic American sport. The result elucidates how people in the past and today develop a sense of place through material and cultural constructions, senses that have profound implications for the perpetuation of cultures and societies. 
The strategic decisions of political masters that shape the world in which we live are at the heart of Baram's (this issue) and A. Smith's (this issue) work on the more recent past. Baram explores the decisions of two empires of the Middle East, the Ottoman and the British, concerning how these colonizers constructed memories using the materials of the ancient city of Jerusalem. Though the Ottoman Empire sought to create a sense of modernity and the future through the construction of clock towers, the British tore down the same towers in favor of constructing a sanitized and supposedly more "native" past for the future. This process of antiquing by the British raises the question for any heritage professional or archaeologist engaged in physically recreating the past: what pasts are erased when one past is resurrected?

A. Smith (this issue) considers today's asylum seekers in Ireland, asking about their materiality as the colonial past meets a globalized present. The willingness of Ireland to embrace asylum seekers but isolate them as their cases are being heard, speaks to that confrontation. Their being quarantined in derelict industrial parks, council housing, and other unused areas contradicts the government's avowed goal of acculturating foreigners to Irish life. Whilst working to be a part of a new country with new cultural practices but still holding onto their own culture, asylum seekers' experiences in these spaces highlight the challenges faced by a Western democracy in a global community.

According to Gazin- Schwartz (this issue), folklore and archaeology can be both complementor and competitor when seeking an understanding of the past, especially in areas where there is a fine line between the material and the immaterial. Her case of the Scottish Highlands raises questions of whether folklore or archaeology is the authoritative source of authenticity. The paper goes on to consider implications of her work for other areas where oral tradition and archaeology tensely come together, such as the U.S. where NAGPRA requires consultations between archaeologists and Native communities. The paper results in an insightful consideration of what is "true" and how archaeology and folklore dance with, between, and around one another in this field of tension.

In our age of treatises on self-reflection, it is worth recalling the ways humor, as well as didactic argument, can effectively provoke critically selfconscious thoughts. In the tradition of Horace Miner's (1956) classic study of the Nacerima, Adrian Praetzellis's (2000) archaeological mystery tale, Death by Theory, Kent Flannery's (1982) satiric Golden Marshalltown, and David Macaulay's (1979) marvelous Motel of the Mysteries, Gero and Loring (this issue) hold the mirror of humor up to ourselves by presenting their discovery of an unexplained artifact pattern of happiness that has been lying dormant in the archaeological literature for many years. Their search for an explanation takes the reader on a tour of recent archaeological theory and 
method, leaving it up to the reader to judge the best explanation. Their questions are a useful guide for befuddled students in theory and method classes. Their wry observations will surely bring nods of recognition, and quite possibly an outright guffaw or two from more experienced practitioners of our craft.

The volume ends with two commentaries, one by Meg Conkey, a noted theorist and scholar of the European Paleolithic, and Claire Smith, an innovative leader in the field of Indigenous Archaeology and tireless organizer of archaeological gatherings. The third commentary is by Wobst, who as usual, gets the last word.

The chapters are truly reflective of the range of influences that H. Martin Wobst has had and continues to have upon his students and others within the discipline of archaeology. We believe that the discipline, with its ongoing fascination with origins, unique and startling objects, and increasingly narrowly drawn phenomenological biographical stories, has yet to come to grips with the simple questions he has been asking about the range of cultural variability and about our species' many millennia-long engagement with the material world. The following papers suggest that the answers lie in unraveling conventional culture histories and opening our minds to the bedazzling range of creativity, accomplishment, sorrow, and strife recorded in the material record of our ancient ancestors and ourselves.

\section{Acknowledgments}

First, and foremost, we would like to thank Martin for all his years of guidance and engagement as a mentor, colleague, and friend. $\mathrm{He}$ has taught us about science and humanism in how we study the past, and in our relationships with one another. He truly is a rare intellectual in our polarized world. We also thank Elizabeth Chilton, who, as Chair of the Department of Anthropology at the University of Massachusetts Amherst, was instrumental in creating the venue at Martin's retirement fete for the presentation of early versions of these papers, which had more polished presentations at a session at the 2011 Annual Meeting of the American Anthropological Association in Montreal, Canada. We would like to thank two other key participants from both of these earlier sessions, James Moore and Stephen Perlman. Of course, we thank Jude Wobst. Finally, we tip our hats to Claire Smith for suggesting that we publish the papers in this most appropriate venue-given Martin's involvement with WAC. We also would like to thank Cristóbal Gnecco and Nick Shepherd, the editors of Archaeologies, for their support and advice. Lastly, we are especially grateful for the productive criticisms, editorial comments, and helpful insights provided by 
three reviewers for this Special Issue; we all benefited from their commitment to this work and to the goals of Archaeologies.

\section{References Cited}

Bruchac, Margaret M., Siobhan Hart, and H. Martin Wobst (editors)

2010. Indigenous Archaeologies: A Reader in Decolonization. Left Coast Press, Walnut Creek, CA.

Flannery, Kent V.

1982. The Golden Marshalltown: A Parable for the Archeology of the 1980s. American Anthropologist 84(2):265-278.

Macaulay, David

1979. Motel of the Mysteries. Houghton Mifflin, New York, NY.

Miner, Horace

1956. Body Ritual among the Naceriema. American Anthropologist 58(3):503507.

Praetzellis, Adrian

2000. Death by Theory: A Tale of Mystery and Archaeological Theory. Altamira, Walnut Creek, CA.

Smith, Claire, and H. Martin Wobst (editors)

2005. Indigenous Archaeologies: Decolonising Theory and Practice. Routledge, London, England.

Wobst, H. Martin

1974a. The Archaeology of Band Society-Some Unanswered Questions. In A Model of Band Society, edited by B.J. Williams pp. v-xiii.

1974b. Boundary Conditions for Paleolithic Social Systems. American Antiquity 39:147-178.

1976. Locational Relationships in Paleolithic Society. Journal of Human Evolution 5:49-58.

1977. Stylistic Behavior and Information Exchange. In For the Director, edited by C. Cleland, Vol. 61, Museum of Anthropology, University of Michigan, Anthropological Papers, Ann Arbor, Michigan, pp. 317-342.

1979. Computers and Coordinates. In Computer Graphics in Archaeology, edited by S. Upham, Vol. 15, Anthropological Research Papers, Arizona State University, Tempe, Arizona, pp. 61-68.

1983. Palaeolithic Archeology: Some Problems with Form, Space, and Time. In Hunter Gatherer Economy in Prehistory: A European Perspective, edited by G. Bailey. Cambridge University Press, Cambridge, pp. 220-225.

1989. Commentary: A Socio-Politics of Socio-Politics in Archaeology. In Critical Traditions in Contemporary Archaeology, edited by Valerie Pinsky and Alison Wylie, pp. 136-140. Cambridge University Press, New York, NY. 
1990. Minitime and Megaspace in the Paleolithic at $18 \mathrm{~K}$ and Otherwise. In In the World at 18,000, edited by Olga Soffer and Clive Gamble. Unwyn and Hyman, London, England, pp. 322-334.

1991a. Discussant's Comments: The Social Dynamics of Goods and Information. Archaeological Perspectives. In Annual Meeting of the Society for American Archaeology, New Orleans, Louisiana.

1991b. The Invention of Europe, Prehistory, and the Utility of Columbus. In Annual Meeting of the American Anthropological Association In the Session Anthropological Interlocutors: Martin Bernal on Black Athena and Its Critics, Chicago, IL.

1992. Towards an "Appropriate Metrology" of Human Action in Archaeology. In Cambridge Conference on Dynamic Systems and Description, edited by Sander van der Leeuw and Colin Renfrew. Edinburgh Unversity Press, Edinburgh, Scotland.

1993a. Mobility and Gene Flow: Some Biological and Social Thoughts on the Paleolithic. In Ela' Qua: Essays in Honor of Richard B. Woodbury, edited by Dorothy Schlotthauer Krass, R. Brooke Thomas, and John W. Cole, pp. 283-291. Department of Anthropology, University of Massachusetts Amherst, Amherst, MA.

1993b. War and Peace, and Crime and Punishment. In Annual Conference of the American Anthropological Association in a Session Crime and Punishment in Preshistory, Washington, DC.

1998. Review: Mind, Modernity and Archaeologists: the Cambridge Archaeological Journal Volumes 1-7. Antiquity 72(278):953-955.

1999. Style in Archaeology or Archaeologists in Style. In Critical Approaches to the Interpretation of Material Culture, edited by Elizabeth S. Chilton. University of Utah Press, Salt Lake City, UT, pp. 118-132.

2000a. Agency in (spite of) Material Culture. In Agency in Archaeology, edited by Marcia-Anne Dobres and John Robb. Routledge, London, England.

2000b. Regions and Late Pleistocene Hunter-Gatherers. In Regional Approaches to Adaptation in Late Pleistocene Western Europe, edited by Gail Larsen Peterkin and Heather A. Price. BAR International Series, Oxford, pp. 221-229.

2005a. Indigenous Inputs into the Archaeogical Mainstream: The Disconnect between Theory and Praxis. In World Archaeological Congress Second Inter-Congress on Indigenous Arcaheologies: The Uses and Abuses of Archaeology for Indigenous Peoples. University of Auckland, New Zealand.

2005b. Power to the (Indigenous) Past and Present! Or: The Theory and Method behind Archaeological Theory and Method. In Indigenous Archaeologies: Decolonizing Theory and Practice, edited by Claire Smith and H. Martin Wobst. Routledge, New York, pp. 17-32. 
2006. Artifacts as Social Interference: The Politics of Saptial Scale. In Confronting Scale in Archaeology issues in Theory and Practice, edited by Gary Lock and Brian Leigh Molyneaux. Springer, New York, pp. 55-64.

2009. Discussant's Comments: Indigenous Knowledges, Difference, Authenticity. In 108th Meeting of the American Anthropological Association, Philadelphia, PA.

2010. Indigneous Archaeologies: A Worldwide Perspective on Human Materialities and Human Rights. In Indigenous Archaeologies: A Reader on Decolonization, edited by Margaret M. Bruchac, Siobhan M. Hart, and H. Martin Wobst, pp. 17-27. Left Coast Press, Walnut Creek, CA.

2011a. Epilogue: Foragers in Hindsight, or Theory and Method Meet History. In Hunter-Gatherer Archaeology as Historical Process, edited by Kenneth E. Sassaman and Donald H. Holly Jr. University of Arizona Press, Tucson, Arizona, pp. 248-257.

2011b. Foraging for Information among Foragers-An Afterword. In Information and Its Role in Hunter-Gatherer Bands, edited by Robert Whallon, William A. Lovis, and Robert K. Hitchcock, pp. 43-57. Costen Institute of Archaeology Press, Los Angeles, CA.

2011c. Matter over Mind: Perishables and the Glorification of Materiality in Archaeology. In Information and Its Role in Hunter-Gatherer Bands, edited by Whallon Robert, William A. Lovis, and K. Robert Hitchcock. Costen Institute of Archaeology Press, Los Angeles, CA, pp. 43-57.

n.d. Toilets as Tools of Teaching. In Teaching Archaeology for Fun, edited by Heather Burke and Claire Smith. Routledge, London, England.

Wobst, H. Martin and Smith, Claire

2000. Unothering Theory and Practice in Archaeololgy. In 31st Chacmool Conference on Indigenous People and Archaeology Session on The Three R's: Respect, Rights, and Responsibilities. 